\begin{tabular}{lll}
\hline Jurnal Teknologi Kimia Unimal & $\begin{array}{l}\text { Jurnal } \\
\text { Teknologi } \\
\text { Kimia } \\
\text { Unimal }\end{array}$ \\
\hline
\end{tabular}

\title{
PENGOLAHAN SAMPAH ORGANIK BUAH- BUAHAN MENJADI PUPUK DENGAN MENGGUNAKAN EFFEKTIVE MIKROORGANISME
}

\author{
Jalaluddin, Nasrul ZA, Rizki Syafrina \\ Jurusan Teknik Kimia, Fakultas Teknik Universitas Malikussaleh \\ Jl. Batam No. 1 Bukit Indah, Blang Pulo, Lhokseumawe 24353 \\ Korespondensi: HP. 081360347108 Email: jalaluddin@yahoo.com
}

\begin{abstract}
ABSTRAK
Pemanfaatan limbah sampah buah-buahan yang sudah tidak terpakai lagi untuk pembuatan pupuk organik cair dengan bantuan Effective mikroorganisme (EM-4). Tahapan kerja dalam penelitian ini adalah tahap persiapan bahan baku dan tahap analisa seperti: analisa $\mathrm{pH}$, nitrogen, fosfor dan kalium. Untuk analisa $\mathrm{pH}$ menggunakan $\mathrm{pH}$ meter dengan hasil terbaik diperoleh 6.89 pada volume EM-4 sebanyak $40 \mathrm{ml}$ dengan waktu fermentasi 9 hari, sedangkan untuk analisa nitrogen, fosfor dan kalium yaitu hasil yang terbaik diperoleh untuk nitrogen sebesar $2.80 \%$ volume EM-4 sebanyak $70 \mathrm{ml}$ dengan waktu fermentasi 15 hari, fosfor yang terbaik diperoleh sebesar $1.16 \%$ pada waktu fermentasi 18 hari dengan volume EM-4 sebanyak $70 \mathrm{ml}$ diukur dengan menggunakan alat spectrophotometer dan kandungan kalium yang terbaik di peroleh 0.64 pada volume EM-4 sebanyak $70 \mathrm{ml}$ dengan waktu fermentasi 18 hari diukur dengan menggunakan alat Atomic Absorption Spectroscopy (AAS).
\end{abstract}

Kata kunci: Pupuk Cair, Fermentasi, Effective Microorganisme (EM-4), Nitrogen, Fosfor

\section{Pendahuluan}

Sampah sayur-sayuran dan buah-buahan merupakan bahan buangan yang biasanya dibuang secara open dumping tanpa pengelolaan lebih lanjut sehingga akan meninggalkan gangguan lingkungan dan bau tidak sedap. Limbah sayuran dan buah-buahan mempunyai kandungan gizi rendah, yaitu protein kasar sebesar 1-15\% dan serat kasar 5-38\%. Penggunaan Effective Microorganisme 4 (EM4) dalam mempercepat pembuatan pupuk cair dianggap sebagai teknologi karena bertujuan untuk mempercepat proses fermentasi. Effective Microorganisme merupakan kultur campuran berbagai jenis mikroorganisme yang bermanfaat 
(bakteri fotosintetik, bakteri asam laktat, ragi aktinomisetes dan jamur fermentasi) yang dapat meningkatkan keragaman mikroba tanah. Pemanfaatan EM4 dapat memperbaiki pertumbuhan dan hasil tanaman.

Beberapa peneliti telah melakukan cara untuk mendapatkan pupuk organik cair dengan bahan baku yang berbeda-beda. Riansyah dan Wesen (2010) pemanfaatan lindi sampah sebagai pupuk cair. Penelitian dilakukan dengan memvariasikan penambahan daun lamtoro dengan variabel tetap: lindi $20 \mathrm{~L}$, aquades $35 \mathrm{~L}$ dan abu tempurung kelapa $2 \mathrm{~kg}$, didapatkan pokok permasalahan meliputi, lindi dalam pembuatan pupuk cair yang paling baik terdapat pada reaktor dengan penambahan $7 \mathrm{~kg}$ daun lamtoro dan $6 \mathrm{~kg}$ bunga dengan waktu 21 hari didapatkan rasio $\mathrm{C} / \mathrm{N}$.

Yunia dkk (2010) pengaruh penggunaan starter terhadap kualitas fermentasi limbah cair tapioka sebagai alternatif pupuk cair. Pada penelitian ini terdapat tiga perlakuan, yaitu pengolahan limbah cair tapioka tanpa starter (Kontrol), pengolahan limbah cair tapioka dengan penambahan Trichoderma koningii (Pupuk A), dan pengolahan limbah cair dengan penambahan EM4 (Pupuk B). Analisis parameter kualitas pupuk seperti C/N, C organik, N, P, K dan pH pada Pupuk A dan Pupuk B berbeda nyata dibandingkan dengan Kontrol. Sementara itu, semua parameter kualitas pada Pupuk A lebih tinggi dibandingkan dengan Pupuk B. Kandungan N, P, K dari Pupuk A sudah memenuhi nilai standar kualitas pupuk sesuai SNI 19- 7030-2004.

Sarjono dkk., (2013) pembuatan pupuk cair dan biogas dari campuran limbah sayuran. Data awal yang diperoleh dari penelitian ini berupa kadar air $88,78 \%$, pH 7,68, dan rasio C/N 33,56. Data akhir dengan hasil optimal diperoleh pada hari ke 25 dengan komposisi EM4 350 ml yaitu unsur N $1 \%$, P 1,98 \%, K $0,85 \%$ dan rasio $\mathrm{C} / \mathrm{N} 30 \%$, total solid $34,78 \%$, Chemical Demand Oxygen (COD) $2386 \mathrm{mg} / \mathrm{L}$, biogas $13 \mathrm{ml}$ dan $\mathrm{pH}$ 5,55.

Berdasarkan uraian di atas pembuatan pupuk cair dari limbah buah-buahan sebagai pupuk alternatif pengganti pupuk kimia sangat cocok dikembangkan. Selain bahan bakunya melimpah juga sangat ekonomis karena tidak memerlukan 
banyak biaya serta melihat kandungan rasio $\mathrm{C} / \mathrm{N}$ yang terdapat pada sampah buah sehingga peneliti berkesimpulan untuk melakukan penelitian terhadap sampah buah-buahan untuk menjadi salah satu bahan baku pembuatan pupuk cair organik. Pupuk cair organik dapat mengurangi ketergantungan petani pada pupuk kimia. Pada penelitian ini diharapkan untuk mengetahui salah satu cara terbaik dalam pembuatan pupuk cair, mengkaji pengaruh waktu perendaman dan volume starter terhadap kualitas pupuk cair dan menganalisa $\mathrm{pH}$, kandungan nitrogen, kandungan fosfor dan kandungan kalium.

\section{Ukuran bahan}

Semakin kecil ukuran bahan, proses pengomposan akan lebih cepat dan lebih baik karena mikroorganisme lebih mudah beraktivitas pada bahan yang lembut daripada bahan dengan ukuran yang lebih besar. Ukuran bahan yang dianjurkan pada pengomposan aerobik antara 1-7,5 cm. Sedangkan pada pengomposan anaerobik, sangat dianjurkan untuk menghancurkan bahan selumat-lumatnya sehingga menyerupai bubur atau lumpur. Hal ini mempercepat proses penguraian oleh bakteri dan mempermudah pencampuran bahan (Yuwono, 2006).

2. Komposisi bahan

Pembuatan pupuk cair dari beberapa macam bahan akan lebih baik dan lebih cepat. Pembuatan pupuk bahan organik dari tanaman akan lebih cepat bila ditambah dengan kotoran hewan.

3. Jumlah mikroorganisme

Dengan semakin banyaknya jumlah mikroorganisme maka proses pembuatan pupuk diharapkan akan semakin cepat.

4. Kelembapan

Umumnya mikroorganisme tersebut dapat bekerja dengan kelembapan sekitar 40-60\%. Kondisi tersebut perlu dijaga agar mikroorganisme dapat bekerja secara optimal. Kelembapan yang lebih rendah atau lebih tinggi akan menyebabkan mikroorganisme tidak berkembang atau mati.

5. Suhu 
Faktor suhu sangat berpengaruh terhadap proses pengomposan karena berhubungan dengan jenis mikroorganisme yang terlibat. Suhu optimum bagi pengomposan adalah $40-60^{\circ} \mathrm{C}$. Bila suhu terlalu tinggi mikroorganisme akan mati. Bila suhu relatif rendah maka mikroorganisme belum dapat bekerja atau dalam keadaan dorman.

\section{Keasaman $(\mathrm{pH})$}

Jika bahan yang dikomposkan terlalu asam, $\mathrm{pH}$ dapat dinaikkan dengan cara menambahkan kapur. Sebaliknya, jika nilai pH tinggi (basa) bisa diturunkan dengan menambahkan bahan yang bereaksi asam (mengandung nitrogen) seperti urea atau kotoran hewan. Keasaman atau $\mathrm{pH}$ dalam tumpukan kompos juga mempengaruhi aktivitas mikroorganisme. Kisaran $\mathrm{pH}$ yang baik sekitar 6,5-7,5 (netral).

Derajat keasaman pada awal proses pengomposan akan mengalami penurunan karena sejumlah mikroorganisme yang terlibat dalam pengomposan mengubah bahan organik menjadi asam organik. Pada proses selanjutnya, mikroorganisme dari jenis lain akan mengkonversikan asam organik yang telah terbentuk sehingga bahan memiliki derajat keasaman yang tinggi dan mendekati normal. (Djuarnani $\mathrm{dkk}$, 2005). Efective mikroorganisme 4 (EM4) merupakan campuran dari mikroorganisme yang menguntungkan. Jumlah mikroorganisme fermentasi didalam EM 4 sangat banyak, sekitar 80 jenis. Mikroorganisme tersebut dipilih yang dapat bekerja secara efektif dalam memfermentasikan bahan organik. Dari sekian banyak mikroorganisme, ada 5 golongan yang pokok yaitu bakteri fotosintetik, lactobacillus sp, streptomices sp, ragi (yeast), dan actinomicetes

Efek Efective mikroorganisme 4 (EM4) bagi tanaman tidak terjadi secara langsung. Penggunaan EM4 akan lebih efisien bila terlebih dahulu ditambahkan bahan organik yang berupa pupuk organik ke dalam tanah. EM4 akan mempercepat fermentasi bahan organik sehingga unsur hara yang terkandung akan terserap dan tersedia bagi tanaman. Selain bermanfaat bagi peningkatan kesuburan tanah dan tanaman, EM4 juga sangat efektif digunakan sebagai 
pestisida hayati yang bermanfaat untuk meningkatkan kesehatan tanaman, EM4 juga bermanfaat untuk sektor perikanan dan peternakan.

Selain berfungsi dalam proses fermentasi dan dekomposisi bahan organik, EM4 juga mempunyai manfaat lain seperti :

1. Membasmi dan mencegah jamur secara biologis

2. Memperbaiki sifat fisik, kimia dan biologi tanah

3. Meningkatkan ketersediaan nutrisi tanah

4. Menekan aktivitas hama dan penyakit pada tanaman

\section{Bahan dan Metode}

Bahan-bahan yang digunakan dalam penelitian ini Ember (drum) digunakan untuk wadah pengomposan, $\mathrm{pH}$ meter digunakan untuk mengukur $\mathrm{pH}$ pada pupuk cair. Blender digunakan untuk penghaluskan sampah buah. Saringan digunakan untuk menyaring antara cairan dan ampas hasil pengomposan. Seperangkat alat distilasi digunakan untuk mendistilasi sampel. Labu ukur digunakan sebagai tempat pengenceran. Erlenmeyer digunakan sebagai wadah cairan pada saat titrasi.Seperangkat alat titrasi digunakan untuk mentitrasi sampel. Pipet tetes digunakan untuk mengambil indikator Feroin. Sampah organik basah (buahbuahan). Cairan EM4 (siap pakai) sebagai bioaktivator atau bakteri untuk fermentasi. $\mathrm{H}_{2} \mathrm{SO}_{4}$ pekat digunakan sebagai bahan tambahan untuk mengekstrak sampel. Aquades digunakan untuk pengenceran. Indikator pp dan $\mathrm{NaOH} 50 \%$ ditambahkan ke sampel sebelum didistilasi dengan ammonium molybadate vanadate. Proses persiapan sampel pupuk organik cair berlangsung secara anaerob yaitu persiapannya sebagai berikut:

Menyiapkan sampah buah-buahan untuk buah dengan ukuran besar dipotong-potong untuk memperkecil ukuran agar mempermudah saat pemblenderan,Buah diblender sampai halus,buah yang halus dimasukkan sebanyak $500 \mathrm{ml}$ dimasukkan kedalam wadah pengomposan. cairan EM4 ditambahkan kedalam wadah pengomposan sesuai dengan volume yang ditentukan, Cairan diaduk hingga homogen, kemudian wadah ditutup dengan rapat. setiap 3 hari sekali dilakukan pengadukan.setelah 9 hari, 12 hari ,15 hari 
dan 18 hari sampel disaring untuk memisahkan antara cairan dan ampas.dan dilakukan analisa pH (derajat keasaman ), kandungan Nitrogen, uji fosfor dan uji kalium.

Dalam proses pembuatan pupuk organik cair setelah proses selesai, beberapa analisa dilakukan antara lain analisa nitrogen.

1. Sampel sebanyak $5 \mathrm{ml}$ dimasukkan kedalam labu ukur $50 \mathrm{ml}$

2. ditambahkan dengan $\mathrm{H}_{2} \mathrm{SO}_{4}$ pekat sebanyak $25 \mathrm{ml}$, dan didihkan dengan pemanas lisrik selama kurang lebih 30 menit.

3. Kemudian setelah dingin, diencerkan dengan aquadest dan dipindahkan kedalam labu ukur $500 \mathrm{ml}$ lalu diisi sampai tanda garis dan dikocok hingga bercampur rata.

4. Lalu diambil $25 \mathrm{ml}$ larutan tersebut dengan pipet ukur dan dimasukkan ke dalam labu distilasi dan ditambahkan air aquadest hingga 1/3 labu distilasi

5. Sebelum larutan didistilasi, tambahkan indicator pp 3 tetes beserta dengan penambahan $\mathrm{NaOH} 40 \%$ sebanyak $20 \mathrm{ml}$ kedalam labu distilasi

6. Proses destilasi dihentikan jika destilat yang tertampung mencapai $75 \mathrm{ml}$.

7. Kemudian dititrasi menggunakan larutan $\mathrm{NaOH} 0,25 \mathrm{~N}$ sampai warna berubah menjadi hijau.

8. Lalu dicatat volume titrasi tepat pada saat terjadi perubahan warna.

9. Dilakukan titrasi blangko seperti diatas

10. Penentuan kadar nitrogen yang dihitung dengan menggunakan rumus:

Total Nitrogen $(\%)=\frac{(V \operatorname{smpl-Vblnk}) x N \times 14,007 \times F P}{m l \operatorname{sampgl} x 1000} \times 100 \%$

Keterangan:

Vsmpl $=0,25 \mathrm{~N} \mathrm{NaOH}$ yang terpakai pada titrasi sampel (ml)

Vblnk $=0,25 \mathrm{~N} \mathrm{NaOH}$ yang terpakai pada titrasi blangko $(\mathrm{ml})$

$\mathrm{N} \quad=$ Normalitas $\mathrm{NaOH}$

$14,007=$ Berat atom nitrogen

$\mathrm{FP}=$ Faktor pengenceran

ml sampel = banyaknya sampel

Kemudian analisa pospor 
1. Diambil masing-masing sampel $5 \mathrm{ml}$ dengan pipet ukur dimasukkan kedalam labu ukur $100 \mathrm{ml}$, dilarutkan dengan aquadest hingga tanda garis dan dikocok hingga bercampur.

2. Kemudian larutan tersebut diambil $20 \mathrm{ml}$ dengan pipet ukur dimasukkan ke dalam ukur $50 \mathrm{ml}$ dan ditambahkan pereaksi Ammonium molybadate vanadate, biarkan selama 10 menit.

3. kemudian diukur dengan spectrophotometer pada panjang gelombang 420 atau $440 \mathrm{~nm}$, lalu dicatat pembacaan absorbansinya. Penentuan kadar fosfor dapat dihitung dengan menggunakan persamaan sebagai berikut:

$$
\begin{aligned}
& \text { ppm } \mathrm{P}=\text { Abs } \times \mathrm{F} \times \mathrm{FP} \\
& \text { Total } \mathrm{P}=\frac{\left(\frac{B N P_{2} \mathrm{O}_{4}}{B N P 0_{4}}\right) x A b s x F x F P}{m l \text { sampel } \times 1000}
\end{aligned}
$$

Analisa kandungan kandungan Kalium dilakukan sebagai berikut:

1. Diambil $5 \mathrm{ml}$ sampel dengan pipet ukur dimasukkan kedalam labu ukur 500 $\mathrm{ml}$, kemudian dilarutkan dengan aquadest dan dikocok hingga bercampur rata.

2. Kemudian larutan tersebut diinjeksikan dengan alat Atomic Absorption Spectrocopy (AAS).

3. Dilakukan spraying larutan sampel kemudian diukur dengan AAS pada panjang gelombang 766-768 nm dan dicatat nilai absorbansinya

4. Penentuan kadar kalium yang dihitung dengan menggunakan rumus:

$$
\text { Total } \mathrm{K}(\%)=\frac{a b s=F \times F P}{m l \text { sampel } \times 1000} \times 100 \%
$$

Dimana:

$$
\begin{aligned}
& \text { Abs }=\text { Absorbansi sampel } \\
& \text { FP }=\text { Faktor pengenceran } \\
& \text { F } \quad=\text { Faktor kalibrasi Spektrofotometer yang digunakan. }
\end{aligned}
$$




\section{Hasil Dan Diskusi}

\subsection{Pengaruh Waktu fermermentasi terhadap pH}

Pengaruh waktu fermentasi terhadap pH dapat dilihat pada Gambar 3.1.

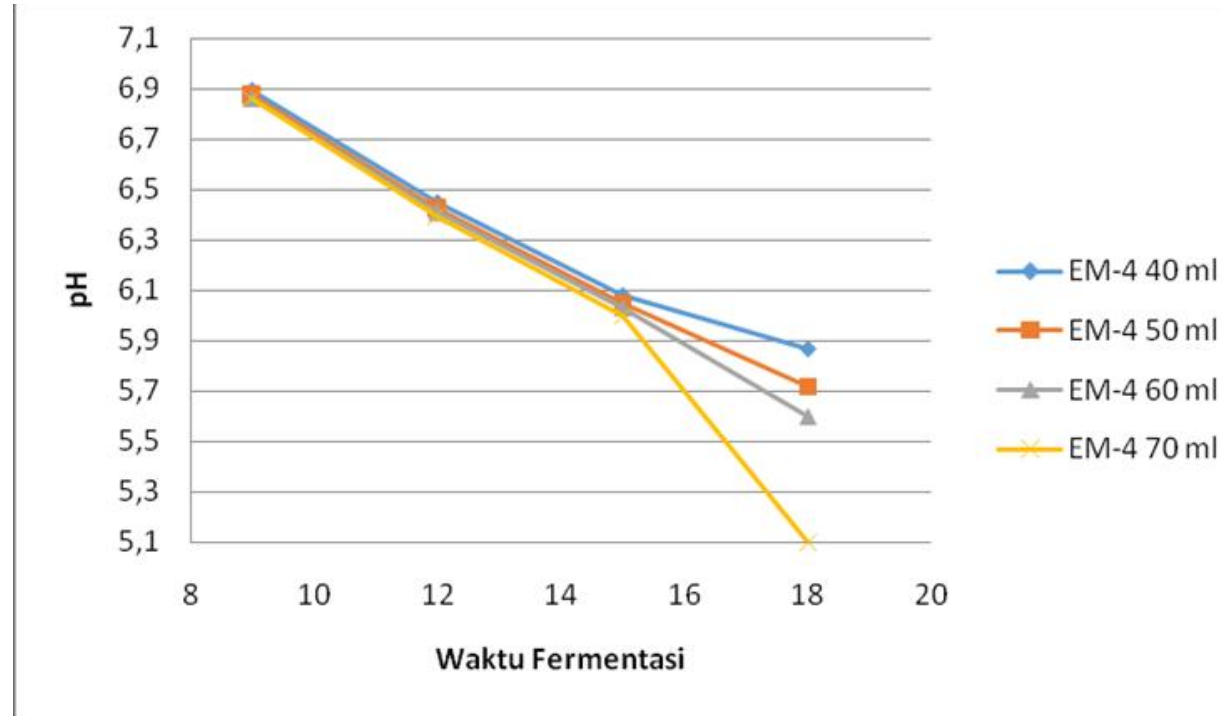

Gambar 3.1 Grafik Pengaruh waktu fermentasi terhadap pH

Seperti yang terlihat pada Gambar 3.1 pengaruh waktu fermentasi dan volume aktivator yang digunakan terhadap kandungan $\mathrm{pH}$ yang didapat. Pada waktu 9 hari dengan volume EM-4 $40 \mathrm{ml}$ pH yang didapat 6.89, volume EM-4 50 $\mathrm{ml} \mathrm{pH}$ yang didapat 6,87 , volume EM-4 $60 \mathrm{ml} \mathrm{pH}$ yang didapat 6.86 dan volume EM-4 $70 \mathrm{ml} \mathrm{pH}$ yang didapat 6.84, lebih tinggi dibandingkan dengan hari-hari selanjutya. Hal tersebut disebabkan karena pada waktu 9 hari mikroorganisme yang terdapat pada sampel tersebut mengalami masa pertumbuhan pada fase awal sehingga kandungan pH yang didapat mendekati netral. Kemudian pada hari 18 dapat kita lihat pada volume EM-4 $40 \mathrm{ml}$ pH yang didapat 5.87, volume EM-4 50 $\mathrm{ml} \mathrm{pH}$ yang didapat 5.72, volume EM-4 $60 \mathrm{ml} \mathrm{pH}$ yang didapat 6.62 sedangkan pada volume EM-4 $70 \mathrm{ml} \mathrm{pH}$ yang didapat 5.10 kandungan $\mathrm{pH}$ yang didapat sangat rendah dibandingkan dengan waktu fermentasi sebelumnya ini disebabkan karena mikroorganisme yang terdapat pada sampel mengalami pertumbuhan secara optimal dikarenakan bahan baku sendiri yang mana kita ketahui bahwa 
pada buah terdapat bermacam-macam kandungan asam yang menyebabkan semakin lama waktu fermentasi dan semakin banyak volume EM-4 yang digunakan maka semakin asam pula kandungan $\mathrm{pH}$ yang didapat.

\subsection{Pengaruh Waktu Fermentasi terhadap Persen Nitrogen (N)}

Pengaruh waktu fermentasi terhadap persen (\%) Nitrogen dilihat pada Gambar 3.2 dibawah ini.

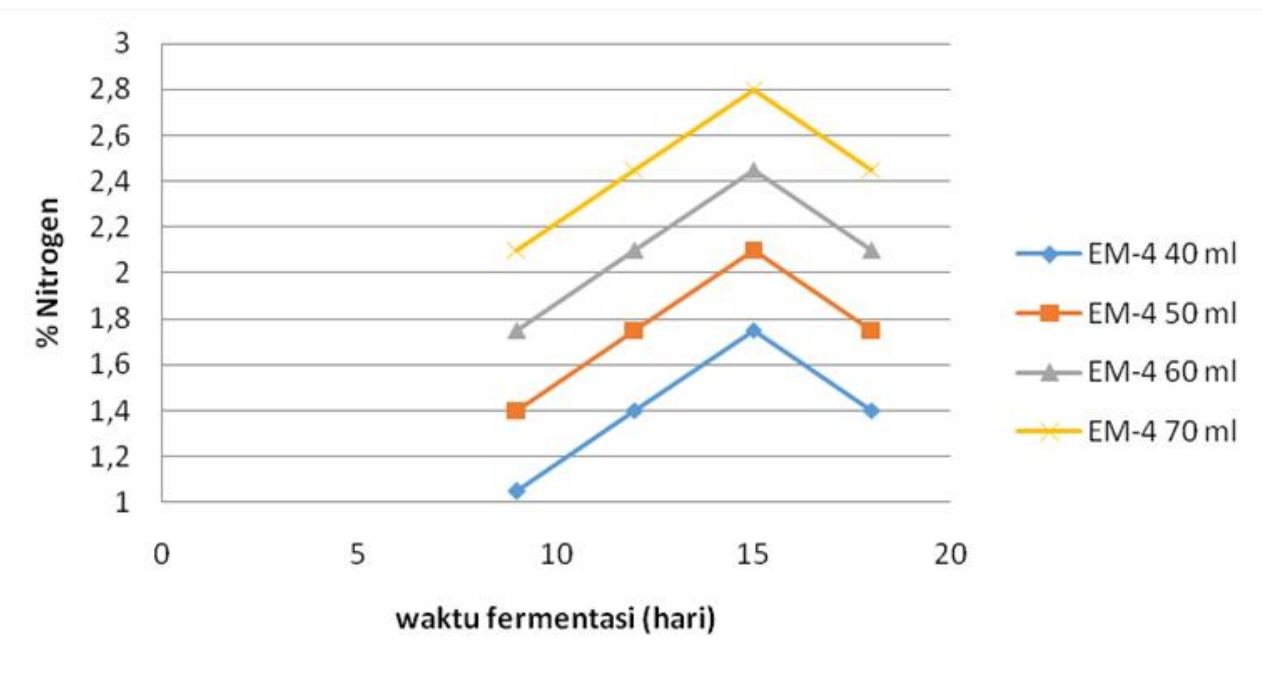

Gambar 3.2 pengaruh waktu fermentasi terhadap \% Nitrogen

Dapat kita lihat pada Gambar 3.2 pengaruh waktu fermentasi terhadap \% Nitrogen yang didapat, dengan memvariasikan penggunaan EM-4 sebagai bioaktivator pada proses fermentasi yang dilakukan. Dimana kadar Nitrogen terendah yang diperoleh terdapat pada volume EM-4 $40 \mathrm{ml}$ pada waktu fermentasi 9 hari yaitu 1,05\%. Hal ini disebabkan karena dalam waktu fermentasi 9 hari terjadi pertumbuhan mikroorganisme fase awal yang merupakan periode adaptasi yakni sejak inokulasi pada medium dilakukan, selama fase awal ini massa sel dapat berubah tanpa adanya perubahan jumlah sel yang terlalu signifikan. Hal ini dapat berpengaruh terhadap tanaman, karena bila kekurangan kadar nitrogen tumbuhan dapat menyebabkan daun kerdil, daun tampak kekuning-kuningan dan sistem perakaran yang terbatas (Tejasarwana, 1998). 
Sedangkan pada waktu fermentasi 12 hari dan 15 hari yaitu 1,40\% dan 1, 75\% meskipun volume EM-4 yang diberikan sama yaitu $40 \mathrm{ml}$ tetapi kadar nitrogen yang didapat semakin meningkat. Begitu juga dengan kadar nitrogen pada hari yang sama tetapi volume EM-4 yang berbeda yaitu $50 \mathrm{ml}, 60 \mathrm{ml}$ dan $70 \mathrm{ml}$ kadar nitrogennya juga meningkat. Hal tersebut disebabkan karena pertumbuhan mikroorganisme yang ada mengalami fase eksponensial yaitu terjadi pembelahan sel yang sangat cepat dan dengan kadar nitrogen yang didapatkan semangkin tinggi dapat berpengaruh pada tanaman karena bila kelebihan unsur hara nitrogen pada tumbuhan dapat mengakibatkan lambat panen, mudah rebah dan serangan terhadap hama atau penyakit. Kemudian pada waktu 18 hari kadar nitrogen yang didapat menurun yaitu 1,40 dengan volume EM-4 $40 \mathrm{ml}$ begitu juga dengan volume EM-4 $50 \mathrm{ml}, 60 \mathrm{ml}$ dan $70 \mathrm{ml}$ pada waktu 18 hari, kadar nitrogen yang didapat menurun dibandingkan hari ke 15 ini dipengaruhi oleh pertumbuhan mikroorganisme dan nutrisi atau makanan yang dibutuhkan oleh mikroorganisme yang tersedia mulai berkurang serta miroorganisme tersebut mulai terurai menjadi suatu asam amino yang dibebaskan kemudian dimetabolisme lebih lanjut (Volk dan Wheeler, 1989), sehingga kadar nitrogen yang didapat menurun.

\subsection{Pengaruh Waktu Fermentasi terhadap Persen Kalium (K)}

Pengaruh waktu fermentasi terhadap persen (\%) Kalium dilihat pada Gambar 3.3.

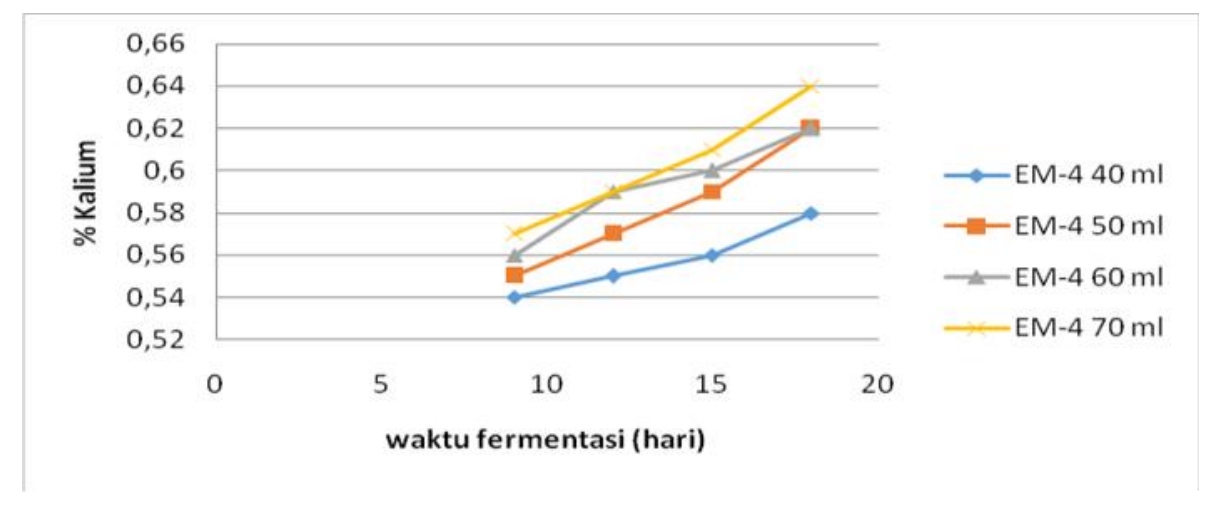

Gambar. 3.3 Grafik Pengaruh Waktu Fermentasi terhadap Persen Kalium (K) 


\subsection{Pengaruh Waktu Fermentasi terhadap Persen Fosfor (P)}

Pengaruh waktu fermentasi terhadap persen (\%) Fosfor dilihat pada Gambar 3.4 dibawah ini.

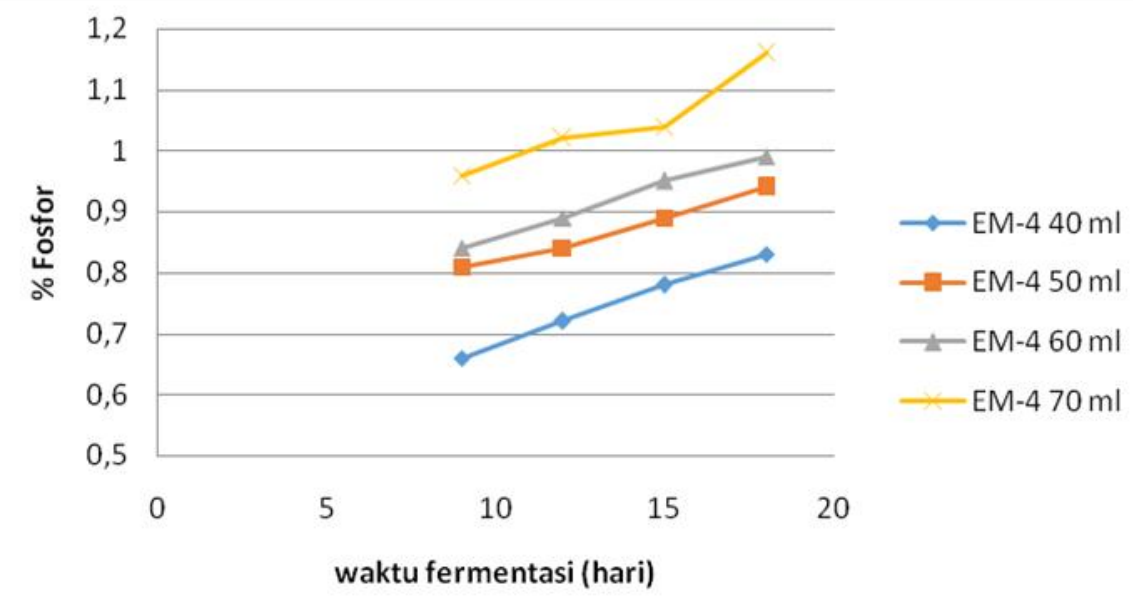

Gambar 3.4 Grafik Pengaruh Waktu Fermentasi terhadap Persen Fosfor (P)

Gambar 3.4 menunjukkan bahwa kandungan fosfor yang didapat sangat dipengaruhi oleh lamanya waktu fermentasi dan volume EM-4 yang divariasikan. Fosfor dalam tanaman berperan dalam pembentukan bunga, buah dan biji serta berperan didalam transfer energi didalam sel tanaman yang tidak dapat digantikan oleh unsur lainnya. Kandungan fosfor terendah yang didapat pada volume EM-4 $40 \mathrm{ml}$ yaitu hari ke 9 dengan kadar fosfor $0.66 \%$, hari ke 12 dengan kadar fosfor $0.72 \%$, hari ke 15 dengan kadar fosfor $0.78 \%$ dan pada hari ke 18 dengan kadar fosfor $0,83 \%$. Hal ini disebabkan karena dalam fermentasi terjadi pertumbuhan mikroorganisme pada fase awal yang merupakan periode adaptasi yakni sejak inokulasi pada medium dilakukan selama fase awal dimana massa sel dapat berubah tanpa adanya perubahan jumlah sel. Setelah perubahan massa selanjutnya terjadi pertumbuhan mikroorganisme bergerak ke fase eksponensial yaitu pada volume EM-4 $70 \mathrm{ml}$ dengan waktu fermentasi 9 hari, 12 hari, 15 hari dan 18 hari dimana mikroorganisme yang ada berkembang secara optimal terhadap jumlah sel 
mikroorganisme yang dihasilkan sehingga kandungan fosfor yang didapat pun semakin meningkat.

\section{Simpulan}

1. Semakin lama waktu fermentasi dan semakin banyak volume EM-4 yang digunakan maka semakin tinggi nilai $\mathrm{N}, \mathrm{P}$ dan $\mathrm{K}$ yang didapat.

2. Nilai $\mathrm{pH}$ yang terbaik diperoleh pada waktu fermentasi 9 hari dengan volume EM- 4 sebanyak $40 \mathrm{ml}$ yaitu 6.89, kandungan nitrogen yang terbaik $2.80 \%$ pada volume EM-4 sebanyak $70 \mathrm{ml}$ dengan waktu fermentasi 15 hari, kandungan kalium sebesar $0.64 \%$ pada volume EM-4 sebanyak $70 \mathrm{ml}$ dengan waktu fermentasi 15 hari, dan fosfor sebesar 1.16 pada volume EM-4 $70 \mathrm{ml}$ dengan waktu fermentasi 18 hari.

\section{5, Daftar Pustaka}

Anonim. 2010. Pupuk Cair. http://id.wikipedia.org/wiki/pupukcair. Diakses, 10 Oktober 2014

Amurwaraharja, I.P., 2006. Analisis Teknologi Pengolahan Sampah Dengan Proses Hirarki Analitik dan Metode Valuasi Kontingensi Study Kasus di Jakarta Timur, Makalah Falsafah Sains. Bogor: Institut Pertanian Bogor, Ilmu Pengetahuan Sumber Daya Alam dan Lingkungan Program Pascasarjana.

Sinaga, D., 2009. Pembuatan Pupuk Cair dari Sampah Organik dengan menggunakan Boisca sebagai Starter. Skripsi. Medan: Universitas Sumatera Utara.

Djuarmani, N., Kristian, B.S., Setiawan, 2005. Cara Tepat Membuat Kompos. Agromedia Pustaka, Jakarta.

Fitriani, Y. 2008. Pembuatan Pupuk Organik Cair dari Limbah Cair Industri Perikanan Menggunakan Asam Asetat dan EM4 (Effective Microorganisme 4). Skripsi. Bogor: Institut Pertanian Bogor.

Hadisuwito, S., 2007. Membuat Pupuk Kompos Cair. PT. Agromedia Pustaka, Jakarta

Indriani, Y.H., 2004. Membuat Kompos Secara Kilat. Penebur Swadaya, Jakarta

Litauditomo., 2007. Mengolah Sampah Rumah Tangga. http://www.lintauditomo.muliply.com. Akses 19 September 2014 
Marsono dan Paulus., 2001. Pupuk Akar Jenis dan Aplikasi. Penebar Swadaya, Jakarta.

Murbandono, L.H.S., 2000. Membuat Kompos. Penebar Swadaya. Jakarta.

Murbondo, L., 2004. Pupuk Organik Padat, Pembuatan Aplikasi. Penebar Swadaya, Jakarta.

Notohadiprawiro, Tejoyuwono. 1995. Logam Berat dalam Pertanian. Jurnal Manusia dan Lingkungan, 7(2): 18-21.

Purwendro. S., dan Nurhidayat. 2006. Mengolah Sampai untuk Pupuk dan Pestisida Organik. Seri Agritekno. Penebar Swadaya, Jakarta.

Riansyah Erwin dan Wesen Putu., 2010. Pemanfaatan Lindi Sampah sebagai Pupuk Cair. Jurnal Ilmiah Teknik Lingkungan Vol. 4 No. 1. Universitas Pembangunan Nasional "Veteran" Jawa Timur.

Sarjono, S.E., Surya, E., dan Herlina, N., 2013. Pembuatan Pupuk Cair dan Biogas dari campuran Limbah Sayuran. Jurnal Teknik Kimia Universitas Sumatera Utara. Medan.

Simamora, S., Salundik, Sriwahyuni dan Surajin. 2005. Membuat Biogas Pengganti Bahan Bakar Minyak Dan Gas dari Kotoran Ternak. Agromedia Pustaka, Bogor.

Suriadikarta, D. A dan Setyorini, D., 2009. Baku Mutu Pupuk Organik. Bogor. Departemen Pertanian. http://www.balittanah.litbang.deptan.go.id. Diakses 19 september 2014.

Sutrisari. S., 2013. Effective Mikroorganisme 4(EM4). http://Suplirahim.1960.blogspot.com. Akses 19 September 2014.

Tejasarwana et al, 1998, Efesiensi Eenggunaan Pupuk Kimia dan Organik, penebar Swadaya, Jakarta.

Volk dan Wheeler., 1989. Mikroobiologi Dasar, Erlangga, Jakarta.

Yunia, C, R., Wirosoedarmo, R., dan Bambang, S., 2010. Pengaruh Penggunaan Starter terhadap Kualitas Fermentasi Limbah Cair Tapioka sebagai Alternatif Pupuk Cair. Jurnal Sumberdaya Alam dan Lingkungan. Universitas Brawijaya., Malang

Yuwono, D., 2006. Kompos dengan Cara Aerob maaupun Anaerob untuk Menghasilkan Kompos yang Berkualitas. Penebar Swadaya. Jakarta. 